\title{
EFEKTIVITAS MODEL PEMBELAJARAN GROUP INVESTIGATION DAN TAI TERHADAP PRESTASI BELAJAR MATEMATIKA DITINJAU DARI MOTIVASI BELAJAR PADA POKOK BAHASAN HIMPUNAN SISWA KELAS VII SMP NEGERI 2 GEGER
}

\author{
Vera Dewi Susanti \\ Dosen Prodi Matematika IKIP PGRI Madiun
}

Email : veradewisusanti@yahoo.com

\begin{abstract}
Abstrak. Tujuan penelitian ini adalah untuk mengetahui: (1) manakah yang lebih efektif antara model pembelajaran group investigation dan model pembelajaran TAI terhadap prestasi belajar matematika dalam pokok bahasan himpunan pada siswa kelas VII SMPN 2 Geger, (2) manakah yang lebih baik antara motivasi tinggi, sedang dan rendah terhadap prestasi belajar matematika dalam pokok bahasan himpunan pada siswa kelas VII SMPN 2 Geger, (3) manakah yang lebih baik antara model pembelajaran group investigation dan model pembelajaran TAI terhadap prestasi belajar matematika pada siswa yang mempunyai motivasi tinggi, sedang maupun rendah dalam pokok bahasan himpunan pada siswa kelas VII SMPN 2 Geger.

Sebagai populasi dalam penelitian ini adalah siswa kelas VII SMPN 2 geger tahun ajaran 2011/2012. Penentuan sampel dengan teknik random sampling yaitu 44 siswa dari kelas eksperimen dan kontrol. Kelas eksperimen menggunakan model pembelajaran group investigation dan kelas kontrol menggunakan model pembelajaran explicit instruction. Teknik pengumpulan data untuk data prestasi belajar menggunakan metode tes dan data motivasi belajar siswa menggunakan metode angket. Uji hipotesis penelitian menggunakan anava dua jalan sel tak sama. Uji lanjut pasca anava menggunakan uji Scheffe.

Kesimpulan dari hasil penelitian ini adalah (1) model pembelajaran group investigation lebih efektif daripada model pembelajaran TAI terhadap prestasi belajar matematika dalam pokok bahasan himpunan pada siswa kelas VII SMPN 2 Geger, (2) prestasi belajar matematika siswa yang mempunyai motivasi belajar tinggi lebih baik daripada siswa yang mempunyai motivasi belajar sedang maupun rendah, dan siswa yang mempunyai motivasi belajar sedang sama baiknya dengan siswa yang mempunyai motivasi belajar rendah dalam pokok bahasan himpunan siswa kelas VII SMPN 2 Geger, (3) tidak terdapat perbedaan prestasi belajar matematika yang signifikan antara model pembelajaran group investigation dan model pembelajaran TAI baik pada siswa yang mempunyai motivasi belajar tinggi, sedang maupun rendah dalam pokok bahasan himpunan pada siswa kelas VII SMPN 2 Geger.
\end{abstract}

Kata Kunci: Efektifitas, Model Pembelajaran Group Investigation, Model Pembelajaran TAI, Prestasi Belajar Matematika, Motivasi

\section{PENDAHULUAN}

Kurikulum Tingkat Satuan Pendidikan (KTSP) merupakan paradigma baru dalam dunia pendidikan. KTSP adalah kurikulum operasional yang disusun oleh dan dilaksanakan di masing-masing satuan pendidikan yang terdiri dari tujuan pendidikan, tingkat satuan pendidikan, struktur dan muatan KTSP, kalender pendidikan dan silabus. Dalam KTSP peserta didik dituntut agar aktif dan kreatif dalam pembelajaran, terutama aktif dalam menggali pengetahuan dari sumber lain sedangkan guru hanya membantu dan menciptakan suasana yang dapat mendorong timbulnya motivasi belajar peserta didik.

Matematika adalah ilmu tentang berfikir dan bernalar tentang bagaimana cara memperoleh kesimpulan-kesimpulan yang tepat dari berbagai keadaan. Karena matematika mempunyai peranan penting dalam perkembangan Ilmu Pengetahuan dan Teknologi (IPTEK). Tetapi masih banyak siswa yang beranggapan bahwa mata pelajaran matematika itu sulit dipahami, bersifat abstrak, menjemukan dan membosankan, sehingga tidak sedikit siswa yang mengalami kesulitan dalam memahaminya. Kegiatan pembelajaran matematika diharapkan mampu membuat siswa terampil menyelesaikan masalah yang dihadapinya baik dibidang matematika maupun dalam bidang lain yang terkait serta mampu membuat siswa berkembang daya nalarnya, sehingga mampu berpikir kritis, logis dan sistematis. Keberhasilan siswa dalam belajar tergantung pada cara penyajian materi pelajaran dan model pembelajaran yang digunakan oleh guru. Guru menyajikan materi pelajaran hanya dengan menggunakan metode-metode yang dikuasainya saja, serta model pembelajaran yang masih berpusat kepada guru. Dalam pelaksanaan proses pembelajaran siswa hanya duduk diam mendengarkan ceramah dari guru. Dalam hal ini guru bersifat aktif sedangkan siswa bersifat pasif. Akibatnya, siswa kurang mendapat pengalaman dalam proses pembelajaran dan tidak dapat 
maksimal dalam mengeksplorasikan potensi yang ada dalam diri siswa. Proses pembelajaran ini tidak sesuai dengan Kurikulum Tingkat Satuan Pendidikan dimana kurikulum ini menuntut siswa aktif dalam proses pembelajaran. Sehingga model pembelajaran ini dinilai kurang efektif digunakan dalam proses pembelajaran.

Siswa masih sulit untuk mencapai hasil tertinggi dalam belajar matematika. Hal ini terbukti pada ketidakberhasilan siswa kelas VII SMPN 2 Geger dalam menguasai salah satu pokok bahasan matematika yaitu pada pokok bahasan himpunan yang $40 \%$ dari jumlah siswa masih memperoleh nilai dibawah 75 pada saat ulangan harian himpunan, sedangkan KKM untuk mata pelajaran matematika adalah 75 . Hal ini berarti bahwa pencapaian prestasi belajar matematika secara umum masih belum sesuai dengan harapan.

Untuk mengatasi permasalahan tersebut, seorang guru harus mempersiapkan model pembelajaran yang tepat dengan tujuan untuk mempermudah dalam pembelajaran matematika yang sesuai dengan karakteristik siswa dan pokok bahasan yang akan disampaikan, kemudian mengevaluasi hasil belajar dengan baik dan cermat sehingga proses pembelajaran dapat berjalan dengan optimal. Hal ini ditujukan supaya proses pembelajaran matematika lebih aktif, kreatif, efektif, dan menyenangkan.

Salah satu model pembelajaran yang bisa dijadikan alternatif oleh guru adalah model group investigation dan TAI. Model group investigation merupakan salah satu bentuk model pembelajaran yang menekankan pada partisipasi dan aktivitas siswa untuk mencari sendiri materi pelajaran yang akan dipelajari melalui bahan-bahan yang tersedia, misalnya dari buku pelajaran atau siswa dapat mencari melalui internet. Tipe ini menuntut para siswa untuk memiliki kemampuan yang baik dalam berkomunikasi maupun dalam keterampilan proses kelompok dan dapat melatih siswa untuk menumbuhkan kemampuan berfikir mandiri. Model ini merupakan salah satu cara yang efektif untuk mengembangkan keterampilan siswa guna meningkatkan kemampuan siswa dalam menerapkan konsep matematika. Sedangkan TAI merupakan pembelajaran yang dirancang khusus untuk mengajarkan matematika. Selain itu TAI merupakan pembelajaran yang melatih kemandirian, daya ingat, kerja sama, diskusi dan kecermatan disamping itu dalam pembelajaran ini diterapkan bimbingan antar teman, yaitu siswa yang pandai membantu siswa yang lemah.

Jika dilihat dari langkah-langkah kedua metode di atas, penerapan metode ini sesuai jika diterapkan pada pokok bahasan himpunan. Diharapkan dengan kedua metode ini mampu mendorong siswa meningkatkan prestasi belajarnya. Berdasarkan kenyataan di lapangan, pokok bahasan himpunan ini merupakan salah satu soal yang paling sering keluar pada soal UAS semester genap. Jadi selain meningkatkan prestasi belajar dalam ulangan harian, diharapakan juga dapat membantu meningkatkan prestasi pada UAS semester genap.

Prestasi belajar merupakan hasil penilaian pendidik terhadap proses belajar dan hasil belajar siswa sesuai dengan tujuan instruksional yang menyangkut isi pelajaran dan perilaku yang diharapkan siswa. Dalam penilaian pembelajaran, untuk meraih prestasi tinggi dalam belajar tidak hanya harus memiliki kecerdasan yang tinggi saja, karena kenyataannya dalam proses belajar mengajar di sekolah ditemukan siswa yang memiliki kecerdasan tinggi memperoleh prestasi yang relatif rendah, namun ada siswa yang walaupun tingkat kecerdasannya relatif rendah dapat meraih prestasi yang lebih tinggi. Itu sebabnya faktor kecerdasan bukan satu-satunya yang menentukan keberhasilan dalam meraih prestasi. Akan tetapi ada faktor lain bisa mempengaruhi proses belajar siswa.

Salah satu faktor yang dapat mempengaruhi prestasi belajar siswa adalah motivasi belajar siswa. Motivasi dapat diartikan sebagai dorongan dasar yang menggerakan seseorang bertingkah laku. Siswa yang mempunyai motivasi belajar tinggi memiliki dorongan yang besar untuk melakukan aktifitas belajar atau memberikan respon positif terhadap aktifitas pembelajaran yang diikuti. Sebaliknya siswa yang memiliki motivasi sedang dan rendah akan mengikuti aktifitas pembelajaran yang tidak serius. Sehingga faktor motivasi belajar siswa sangat menarik untuk diteliti, dalam arti seberapa jauh motivasi ini mempengaruhi prestasi belajar matematika.

\section{METODE PENELITIAN}

Penelitian ini dilakukan di SMP Negeri 2 Geger kelas VII tahun ajaran 2011/2012. Penelitian ini termasuk penelitian kuantitatif. Sesuai dengan tujuan penelitian, maka dalam penelitian ini menggunakan metode eksperimen yang menggunakan desain anava 2 jalan sel tak sama. Faktor pertama (A) adalah model pembelajaran Group Investigation. Faktor kedua (B) adalah model pembelajaran TAI.

Teknik pengumpulan data yang digunakan dalam penelitian kuantitatif ini adalah metode angket yang digunakan untuk mengukur motivasi siswa terhadap pelajaran matematika dan metode tes yang digunakan untuk mengukur prestasi belajar matematika siswa. Angket yang digunakan dalam penelitian kuantitatif ini adalah soal pilihan ganda dan tes yang digunakan adalah tes individu dengan bentuk soal pilihan ganda.

Angket dianalisis per item dengan cara dikelompokkan menurut jenis dan kategori jawaban. Adapun skor yang diberikan terhadap pernyataan 
positif adalah 5, 4, 3, 2, 1 dengan rincian sangat setuju 5 , setuju 4 , ragu-ragu 3 , tidak setuju 2 , dan sangat tidak setuju 1 . Sedangkan untuk pernyataan negatif diberi skor 1, 2, 3, 4, 5 dengan rincian sangat setuju 1 , setuju 2, ragu-ragu 3 , tidak setuju 4 , dan sangat tidak setuju 5.

Prestasi belajar siswa diukur dengan menggunakan tes yang diberikan pada akhir pembelajaran. Tes yang digunakan adalah tes objektif dengan bentuk soal pilihan ganda yang terdiri dari 20 soal yang dikerjakan dalam waktu 45 menit. Penilaian tes dilakukan untuk menilai prestasi belajar perorangan (individu).

\section{HASIL PENELITIAN}

Data yang terkumpul dalam penelitian ini terdiri atas data keadaan awal sebelum diberi perlakuan berupa nilai ujian tengah semester, data prestasi belajar siswa didapat dari pemberian tes sesudah pembelajaran, data motivasi belajar siswa yang terdiri dari motivasi tinggi, sedang dan rendah. Data diperoleh dari kelas VIIA sebagai kelas eksperimen dengan menggunakan model pembelajaran Group Investigation dan kelas VIIB sebagai kelas kontrol dengan menggunakan model pembelajaran TAI.

\section{Data Prestasi Belajar Siswa}

Dari data sebelumnya rata-rata nilai UH pokok bahasan himpunan untuk kelas eksperimen VII A dengan jumlah siswa 22 yaitu 67,36, sedangkan untuk kelas kontrol yaitu VII B dengan jumlah siswa 22 yaitu 63,91. Setelah dilakukan penelitian dihasilkan nilai rata-rata hasil tes prestasi matematika pokok bahasan himpunan dari 20 soal terhadap 22 siswa untuk kelas eksperimen 74,32. Sedangkan pada kelas kontrol dari 22 siswa rata-rata hasil tes prestasinya adalah 65,91 .

\section{Data Motivasi Belajar Siswa}

Rata-rata motivasi belajar siswa pada kelas VIIA (kelompok eksperimen) yang mempunyai motivasi tinggi sejumlah 8 siswa, kategori motivasi belajar sedang berjumlah 9 siswa dan kategori motivasi belajar rendah berjumlah 5 siswa. Sedangkan nilai rata-rata prestasi belajar matematika siswa pada kategori motivasi belajar tinggi yaitu 81,25 , kategori motivasi belajar sedang yaitu 72,78 dan kategori motivasi belajar rendah yaitu 66 .

Untuk kelas VIIB (kelompok kontrol) diperoleh jumlah siswa dengan kategori motivasi belajar tinggi berjumlah 5 siswa, kategori motivasi belajar sedang berjumlah 8 siswa dan kategori motivasi belajar rendah berjumlah 9 siswa. Sedangkan nilai rata-rata prestasi belajar matematika siswa pada kategori motivasi belajar tinggi yaitu 74 , motivasi belajar sedang yaitu 65 dan motivasi belajar rendah yaitu 62,22 .
Berdasarkan data tersebut menunjukkan bahwa siswa yang mempunyai motivasi tinggi mempunyai prestasi belajar yang lebih baik daripada siswa yang mempunyai motivasi sedang dan rendah. Sedangkan siswa yang mempunyai motivasi sedang mempunyai prestasi belajar yang lebih baik daripada siswa yang mempunyai motivasi rendah.

\section{Hasil Pengujian Hipotesis \\ 1. Analisis Uji Pendahuluan}

a. Uji Normalitas

Uji ini digunakan untuk mengetahui apakah data yang digunakan untuk uji keseimbangan pada kelompok eksperimen dan kelompok kontrol memenuhi persyaratan uji t. Uji normalitas pada penelitian ini menggunakan metode Lilliefors dengan tingkat signifikan $\alpha=0,05$.

Hasil analisis uji normalitas untuk kelompok eksperimen dengan tingkat signifikan $\alpha=0,05$ menunjukkan bahwa $\mathrm{L}=$ 0,1362 . Daerah kritik untuk uji ini $\mathrm{DK}=$ $\left\{\mathrm{L} / \mathrm{L}>\mathrm{L}_{0,05 ; 22}=0,183\right\}$. Ini berarti $\mathrm{H}_{0}$ diterima, sehingga data sampel random untuk kelompok eksperimen berasal dari populasi yang berdistribusi normal.

Uji normalitas Lilliefors pada kelompok kontrol dengan tingkat signifikan $\alpha=0,05$ menunjukkan bahwa $\mathrm{L}=0,0715$. Daerah kritik untuk uji ini $\mathrm{DK}=\left\{\mathrm{L} / \mathrm{L}>\mathrm{L}_{0,05 ; 22}=\right.$ $0,183\}$. Ini berarti $\mathrm{H}_{0}$ diterima, sehingga data sampel random untuk kelompok kontrol berasal dari populasi yang derdistribusi normal.

b. Uji Homogenitas

Selain uji normalitas perlu dilakukan uji homogenitas. Jika data yang digunakan untuk uji keseimbagan normal dan homogen, maka uji keseimbangan antara kelompok eksperimen dan kelompok kontrol dengan uji $\mathrm{t}$ dapat digunakan. Hasil analisis uji homogenitas dengan uji Bartlett pada tingkat signifikan $\alpha=0,05$ menunjukkan bahwa $\chi_{\text {obs }}^{2}$ $=0,0525$. Daerah kritik untuk uji ini DK $=$ $\left\{\chi^{2} / \chi^{2}>\chi_{0,05 ; 1}^{2}=3,841\right\}$. Ini berarti $\mathrm{H}_{0}$ diterima, sehingga dapat disimpulkan bahwa data sampel random kedua kelompok homogen.

c. Uji Keseimbangan

Sebelum melakukan eksperimen terhadap kedua kelompok, penulis melakukan uji keseimbangan untuk mengetahui apakah kelompok eksperimen dan kelompok kontrol mempunyai kemampuan yang sama. Hasil analisis data dengan menggunakan uji t pada tingkat signifikan $\alpha=0,05$ menunjukkan bahwa $t_{\text {hit }}=1,4706$. Daerah kritik untuk uji ini $D K=\left\{t / t<-t_{\alpha / 2 ; n 1+n 2-2}=-1,960\right.$ atau $t / t>$ $\left.\mathrm{t}_{\alpha / 2 ; \mathrm{n} 1+\mathrm{n} 2-2}=1,960\right\}$. Ini berarti $\mathrm{H}_{0}$ diterima, 
sehingga disimpulkan bahwa kedua kelompok mempunyai kemampuan yang sama.

\section{Analisis Uji Hipotesis}

a. Uji Prasyarat

1) Uji Normalitas

Uji ini digunakan untuk mengetahui apakah data sampel random berasal dari populasi yang berdistribusi normal. Dalam penelitian ini, uji normalitas menggunakan metode Lilliefors dengan tingkat signifikan $\alpha=$ 0,05. Rangkuman hasil uji normalitas dapat dilihat pada tabel 1, sebagai berikut:

Tabel 1. Uji Normalitas

\begin{tabular}{|c|c|c|c|c|}
\hline Kelompok & $\mathbf{L}_{\mathbf{o b s}}$ & DK & Keputusan & Kesimpulan \\
\hline Eksperimen & 0,1471 & 0,183 & Diterima & Normal \\
\hline Kontrol & 0,1382 & 0,183 & Diterima & Normal \\
\hline Motivasi tinggi & 0,1210 & 0,234 & Diterima & Normal \\
\hline Motivasi sedang & 0,1688 & 0,206 & Diterima & Normal \\
\hline Motivasi rendah & 0,1909 & 0,227 & Diterima & Normal \\
\hline
\end{tabular}

Dari rangkuman analisis uji normalitas menunjukkan bahwa data kelompok eksperimen, kontrol, maupun kelompok kategori motivasi berasal dari populasi yang berdistribusi normal.

2) Uji Homogenitas

Uji ini digunakan untuk mengetahui apakah sampel random data amatan pada kelompok eksperimen, kontrol dan kelompok kategori motivasi homogen. Dalam penelitian ini uji homogenitas yang digunakan adalah uji Bartlett dengan tingkat signifikan $\alpha=$ 0,05 . Rangkuman hasil penelitian uji homogenitas dapat dilihat pada tabel 2, sebagai berikut:

Tabel 2. Uji Homogenitas

\begin{tabular}{|l|c|c|c|c|}
\hline \multicolumn{1}{|c|}{ Kelompok } & $\mathbf{X}_{\text {obs }}^{\mathbf{2}}$ & DK & Keputusan & Kesimpulan \\
\hline Eksperimen $\left(\mathrm{a}_{1}\right)$ dan Kontrol $\left(\mathrm{a}_{2}\right)$ & 0,0015 & 3,841 & $\mathrm{H}_{0}$ diterima & Homogen \\
\hline $\begin{array}{l}\text { Motivasi tinggi }\left(\mathrm{b}_{1}\right) \text {, sedang }\left(\mathrm{b}_{2}\right), \\
\text { dan reBdah }\left(\mathrm{b}_{3}\right)\end{array}$ & 3,6027 & 5,991 & $\mathrm{H}_{0}$ diterima & Homogen \\
\hline
\end{tabular}

rdasarkan hasil rangkuman analisis uji homogenitas tersebut menunjukkan bahwa data amatan kelompok eksperimen, kontrol maupun masing-masing kategori motivasi homogen.

b. Keputusan Uji Hipotesis

Berdasarkan analisis uji persyaratan menunjukkan bahwa sampel random data amatan berasal dari populasi yang berdistribusi normal masing-masing kategori variabel data amatan homogen. Dengan demikian analisis uji hipotesis dengan teknik analisis variansi dapat dilanjutkan. Rangkuman hasil uji hipotesis pada analisis varian $2 \times 3$ pada tingkat signifikan $\alpha=0,05$ dapat dilihat pada tabel 3 sebagai berikut:

Tabel 3. Uji Hipotesis

\begin{tabular}{|l|c|c|c|c|c|c|}
\hline \multicolumn{1}{|c|}{ Sumber } & JK & $\mathrm{dk}$ & $\mathrm{RK}$ & $\mathrm{F}_{\text {obs }}$ & $\mathrm{F} \alpha$ & Keputusan \\
\hline Model (A) & 405,6623 & 1 & 405,6623 & 5,5279 & 4,07 & Ditolak \\
\hline Motivasi(B) & 1292,3898 & 2 & 646,1949 & 8,8056 & 3,25 & Ditolak \\
\hline Interaksi(AB) & 32,4719 & 2 & 16,2359 & 0,2212 & 3,25 & Diterima \\
\hline Galat & 2788,6112 & 38 & 73,3845 & - & - & - \\
\hline Total & 4519,1352 & 43 & - & - & - & - \\
\hline
\end{tabular}

Dari rangkuman analisis varian menunjukkan bahwa :

1) Terdapat perbedaan efek antar baris terhadap variabel terikat.
2) Terdapat perbedaan efek antar kolom terhadap variabel terikat.

3) Tidak ada interaksi baris dan kolom terhadap variabel terikat. 
c. Analisis Uji Lanjut

Berdasarkan hasil analisis uji hipotesis menunjukkan bahwa efek faktor B ditolak, maka perlu dilakukan uji lanjut untuk melihat perbedaan yang terjadi pada setiap kategori.
Uji lanjut yang digunakan dalam penelitian ini adalah uji Scheffe'. Rangkuman hasil analisis dengan uji Scheffe' pada tingkat signifikan $\alpha=0,05$ dapat dilihat pada tabel 4 sebagai berikut:

Tabel 4. Uji Lanjut

\begin{tabular}{|c|c|c|c|c|}
\hline $\begin{array}{c}\text { Faktor } \\
\text { Komparasi }\end{array}$ & $\mathbf{H}_{\mathbf{0}}$ & $\mathbf{F}_{\text {obs }}$ & $\mathbf{D K}$ & Keputusan \\
\hline \multirow{3}{*}{ Motivasi (B) } & $\mu_{\mathrm{b} 1}=\mu_{\mathrm{b} 2}$ & 8,7601 & 6,50 & $\mathrm{H}_{0}$ ditolak \\
\cline { 2 - 5 } & $\mu_{\mathrm{b} 1}=\mu_{\mathrm{b} 3}$ & 20,3725 & 6,50 & $\mathrm{H}_{0}$ ditolak \\
\cline { 2 - 5 } & $\mu_{\mathrm{b} 2}=\mu_{\mathrm{b} 3}$ & 3,2238 & 6,50 & $\mathrm{H}_{0}$ diterima \\
\hline
\end{tabular}

Dari rangkuman hasil analisis uji scheffe' menunjukkan bahwa prestasi belajar siswa yang mempunyai motivasi belajar tinggi berbeda secara signifikan dengan siswa yang mempunyai motivasi belajar sedang, prestasi belajar siswa yang mempunyai motivasi belajar tinggi berbeda secara signifikan dengan siswa yang mempunyai motivasi belajar rendah, prestasi belajar siswa yang mempunyai motivasi belajar sedang tidak berbeda secara signifikan dengan siswa yang mempunyai motivasi

\section{SIMPULAN}

Berdasarkan penafsiran hasil analisa data di atas maka kesimpulan hipotesisnya antara lain:

1. Terdapat perbedaan pengaruh antara model pembelajaran group investigation dan model pembelajaran TAI terhadap prestasi belajar matematika siswa pada pokok bahasan himpunan siswa kelas VII SMPN 2 Geger.

2. Terdapat perbedaan prestasi belajar matematika antara siswa yang mempunyai motivasi belajar tinggi lebih baik daripada motivasi belajar sedang dan motivasi belajar sedang lebih baik daripada motivasi belajar rendah pada pokok bahasan himpunan siswa kelas VII SMPN 2 Geger.

3. Tidak terdapat interaksi antara model pembelajaran group investigation dan model pembelajaran TAI pada siswa yang mempunyai motivasi belajar tinggi, sedang maupun rendah terhadap prestasi belajar matematika pada pokok bahasan himpunan siswa kelas VII SMPN 2 Geger.

\section{SARAN} berikut.:

Adapun saran-saran tersebut antara lain sebagai

1. Bagi Sekolah

Hasil penelitian ini hendaknya dapat dipergunakan sebagai masukan dan pertimbangan bagi SMPN 2 Geger untuk melakukan perubahan dalam pengajaran maupun dalam penggunaan model pembelajaran group investigation guna meningkatkan prestasi belajar matematika siswa.

2. Bagi Guru

Guru dalam menyampaikan pelajaran atau materi hendaknya menggunakan model pembelajaran yang tepat, misalnya model pembelajaran group investigation. Selain itu, guru juga harus memperhatikan motivasi belajar yang dimiliki setiap siswa. Hal ini dilakukan agar prestasi belajar matematika siswa lebih meningkat dan lebih baik daripada sebelumnya.

3. Bagi Siswa

Pada kegiatan proses belajar mengajar siswa harus lebih aktif, termotivasi agar dapat memahami materi yang disampaikan guru dan memperoleh hasil yang optimal.

4. Bagi Orang Tua

Orang tua diharapkan lebih memperhatikan, mampu membantu dan membimbing anak ketika belajar di rumah. Dukungan dan motivasi dari orang tua akan membantu anak dalam meraih prestasi belajar yang lebih baik.

5. Bagi Peneliti Selanjutnya

Peneliti yang akan mengadakan penelitian yang serupa hendaknya menggunakan materi dan subyek penelitian yang berbeda yaitu pada siswa SMA dan SMK. Sehingga siswa dapat menyerap materi secara maksimal. Selain itu, perlu dianalisis apakah motivasi siswa dapat meningkatkan prestasi belajar matematika.

\section{DAFTAR PUSTAKA}

Asmil Dwi Mufida. 2010. Model, Metode dan Strategi Pembelajaran. Jakarta : PT Grasindo

Budiyono. 2004. Statistik Untuk Penelitian. Surakarta: Sebelas Maret University Press

Cholid Narkubo dan H. Abu Achmadi. 2003. Metodologi Penelitian. Jakarta: PT Bumi Aksara

Hadari Nawawi. 2005. Metode Penelitian Bidang Sosial. Yogyakarta: Gadjah Mada University Press 
Hamzah B. Uno. 2007. Model Pembelajaran Menciptakan Proses Belajar Mengajar yang Kreatif dan Efektif. Jakarta:PT Bumi Aksara

H. Baharuddin dan Esa Nur Wahyuni. 2007. Teori Belajar \& Pembelajaran. Jogjakarta: Ar-Ruzz Media

Iqbal Hasan. 2004. Analisis Data Penelitian dengan Statistik. Jakarta: PT Bumi Aksara

Mohamad Nur dan Prima Retno Wikandari. 2008. Pengajaran Berpusat Kepada Siswa dan Pendekatan Konstruktivis dalam Pengajaran. Surabaya: PSMS UNESA

Mulyasa, E. 2002. Manajemen Berbasis Sekolah.

Bandung: PT Remaja Rosdakarya Offset.

Pupuh Fathurrohman dan Sobry Sutikno, M. 2007. Strategi Belajar Mengajar. Bandung: PT. Refika Aditama

Reni Akbar Hawadi. 2004. Akselerasi. Jakarta: PT Grasindo

Sugiyono. 2007. Metode Penelitian Kuantitatif Kualitatif dan $R \& D$. Bandung: Alfabeta

2008. Statistik untuk Penelitian. Bandung:

CV Alfabeta

Suharsimi Arikunto. 2003. Dasar-Dasar Evaluasi

Pendidikan. Jakarta: Bumi

Aksara.

Jakarta: PT Rineka Cipta

2005. Manajemen Penelitian. 2006. Penelitian Tindakan

Kelas. Jakarta: Bumi Aksara

Slameto. 2003. Belajar dan Faktor-faktor yang Mempengaruhinya. Jakarta: PT Rineka Cipta
2010. Belajar dan Faktor-Faktor yang Mempengaruhi. Jakarta: PT. Rineka Cipta

Syaiful Bahri Djamarah. 2006. Psikologi Belajar. Jakarta: PT. Rineka Cipta

Tanwey Gerson Ratumanan. 2002. Belajar dan Pembelajaran. Surabaya: Unesa Uneversity Press

Trianto. 2009. Mendesain Model Pembelajaran Inovatif-Progresif: Konsep, Landasan, dan Implementasinya Pada Kurikulum Tingkat Satuan Pendidikan (KTSP). Jakarta: Kencana Prenada Media Group

Yatim Riyanto. 2009. Paradigma Baru Pembelajaran Sebagai Referensi Bagi Pendidik dalam Implementasi Pembelajarn yang Efektif dan Berkualitas. Jakarta: Kencana Prenada Media Group

Zaenal Arifin. 2009. Evaluasi Pembelajaran. Bandung: Remaja Rosdakarya.

http://asnaldi.multiply.com/journal/item/5 di akses 20 Maret 2012

http://ekocin.wordpress.com/2011/06/17/modelpembelajaran-teams-games-tournaments-tgt/ diakses 20 Maret 2012

http://learning-withme.blogspot.com/2006/09/pembelajaran.html diakses 20 Maret 2012

http://wawan-junaidi.blogspot.com/2011/04/belajarmatematika.html diakses 20 Maret 2012

http://wywld.wordpress.com/2009/10/12/modelpem belajaran diakses 22 Maret 2012 